\title{
Prototype Sistem Informasi Administrasi Pengadaan Barang Dengan Teknologi RFID
}

\author{
Marini \\ Program Studi Sistem Informasi STMIK ATMA LUHUR \\ arinimarini44@atmaluhur.ac.id
}

\begin{abstract}
Goods Procurement Administration Information System is the procurement of ATK / stock of goods as providers or suppliers of goods for smooth operations. Procurement Administration Information System Goods for recording and storing data on goods procurement often occur errors. With the information system prototype Procurement of goods by using Radio Frequency Identification (RFId) technology to be created, it is expected that the process of requesting, procuring, distributing and reporting is more useful to be applied in the future. Software Development Model namely the waterfall model and the Object Oriented Analysis Design (OOAD) model, which is data collection through interviews, observation, object analysis and documentation. The tools used in developing system analysis are Activity diagrams, Use cases, Package Diagrams, Class Diagrams, Deployment Diagrams. Administration Information Systems Procurement of Goods at PT. Bakti Timah Pangkalpinang Hospital Administrative Procurement Information System at PT. Bakti Timah Hospital Pangkalpinang is carried out using a SWOT analiss, system design is described by UML modeling, Programming Language uses VB.Net 2008 and the database uses Mysql. The results of this study are prototype information systems Procurement of goods using Radio Frequency Identification (RFId) Technology at PT. Bakti Timah Hospital Pangkalpinang.
\end{abstract}

Keywords : Prototype, Procurement Administration System, Radio Frequency Identification Technology

\begin{abstract}
Abstrak
Sistem Informasi Administrasi Pengadaan Barang adalah pengadaan stok barang ATK/ sebagai penyedia atau penyuplai atas barang untuk kelancaran operasional. Sistem Informasi Administrasi Pengadaan Barang pencatatan dan penyimpanan data pengadaan barang sering terjadi kesalahan. Dengan adanya Prototipe sistem informasi Pengadaan barang Dengan menggunakan Teknologi Radio Frequency Identification (RFId) yang akan dibuat ini, diharapkan proses permintaan, pengadaan, pendistribusian dan pelaporan lebih bermanfaat untuk di terapkan di masa yang akan datang. Model Pengembangan Perangkat lunak yaitu model waterfall dan model Object Oriented Analysis Design (OOAD) yaitu pengumpulan data melalui wawancara, observasi, analisis objek dan dokumentasi. Tool yang digunakan dalam pengembangan Analisa sistem adalah Activity diagram, Use Case, Package Diagram, Class Diagram, Deployment Diagram. Sistem Informasi Administrasi Pengadaan Barang pada PT. Rumah Sakit Bakti Timah Pangkalpinang Sistem Informasi Administrasi Pengadaan Barang pada PT. Rumah Sakit Bakti Timah Pangkalpinang dilakukan menggunakan analiss SWOT, perancangan sistem digambarkan dengan pemodelan UML, Bahasa Pemrograman menggunakan VB.Net 2008 dan database menggunakan Mysql . Hasil dari penelitian ini adalah Prototipe sistem informasi Pengadaan barang Dengan Menggunakan Teknologi Radio Frequency Identification (RFId) pada PT. Rumah Sakit Bakti Timah Pangkalpinang.
\end{abstract}

Keywords : Prototype, Sistem Adminitrasi Pengadaan, Teknologi Radio Frequency Identification

\section{PENDAHULUAN}

RFId (Radio Frequency Identification) atau Identifikasi Frekuensi Radio merupakan teknologi untuk mengidentifikasi manusia atau benda secara otomatis atau untuk menyimpan dan mengambil data dengan jangkauan jarak jauh. Dengan adanya RFId sebagai penunjang medis memudahkan tenaga kesehatan dalam melakukan pengidentifikasian, penelusuran keberadaan kebutuhan peralatan medis yang diperlukan meskipun jarak jauh. Dengan system ini bagian pengadaan barang lebih terkontrol keluar masuknya kebutuhan barang antar bagian. RFId 
tersebut dapat dibaca oleh sensor yang dipasang dilangit-langit yang dapat mencatat dengan tepat waktu dan keluarnya seseorang.

Penggunaan sistem barcode bukan merupakan barang yang tidak terlalu baru namun didalam sistem barcode masih bisa terjadi beberapa kesalahan yang fatal yaitu seperti kesalahan print out pada gelang, jika salah satu garis itu hilang maka sudah merubah arti dari pembacaan di sistem barcode dan pada akhirnya akan membahayakan pengontrolan barang. Dengan penggabungan teknologi RFId serta sistem informasi maka sistem manajemen pada Bagian Pengadaan Barang serta pendatan barang bisa lebih efisien dan lebih terkontrol oleh pihak rumah sakit. Aplikasi merupakan suatu perangkat lunak (software) yang digunakan untuk memudahkan Pekerjaan bagi setiap perusahaan atau orang berhubungan dengan Informasi. Dalam praktiknya sebuah aplikasi dapat dibangun dengan menggunakan bahasa pemrograman Baik itu Visual Basic 2006 ataupun Visual Basic 2008.

Pengembangan sistem informasi administrasi rumah sakit, khususnya pengadaan barang menggunakan RFId Radio Frequency Identification (RFId) adalah suatu metoda penyimpan dan mengambil kembali data melalui gelombang radio menggunakan suatu peralatan yang disebut RFId tags atau transponders.

Didalam penelitian ini telah ditetapkan batasan-batasan masalah yang akan diulas dan dibuatkan penyelesaiannya, yaitu: bagaimana cara merancang Prototype Sistem Informasi Pengadaan Barang dengan RFId.

Tujuan merancang Prototype Sistem informasi Pengadaan barang dengan RFId adalah Mengetahui cara menggunakan sistem informasi berbasis komputer dengan menggunakan RFId (Radio Frequency Identification), Menjelaskan Teknologi RFId Di Rumah Sakit Cara Kerja RFId, Bagaimana Cara Pengoprasian Alat RFId, Manfaat Aplikasi Dari Pengadopsian Teknologi RFId, Kelebihan Dari RFId, Hambatan Dari Pengadopsian Teknologi RFId.

\section{KERANGKA TEORI}

\subsection{Teknologi Radio Frequency Identification}

Teknologi Radio Frequency Identification (RFId) adalah sebuah pengembangan teknologi pengambilan data secara otomatik atau pengenalan atau identifikasi obyek.Komponen utama sistem RFId terdiri dari tiga komponen utama yaitu tag, reader dab basis data. Sistem RFId merupakan suatu tipe sistem identifikasi otomatis yang bertujuan untuk memungkinkan data ditransmisikan oleh alat portable yang disebut tag, yang dibaca oleh reader RFId dan dapat diproses menurut kebutuhan dari aplikasi tertentu. Pembaca RIFd adalah merupakan penghubung antara software aplikasi dengan antena yang akan meradiasi gelombang radio ke tag RFId. Gelombang radio yang diemisi oleh antena berpropagasi pada ruangan disekitarnya. Akibatnya data dapat berpindah secara wireless ke tag RFId yang berada berdekatan dengan antena (Prabhu, et all). Sistem RFId menggunakan rentang frekuensi yang berlisesi dan dapat diklarifikasi sebagai peralatan industrialscientific-medical atau peralatan berjarak pendek yang dizinkan FCC. Pemanfaatan Teknologi RFId adalah untuk pelacakan produk, kini sistem RFId menjadi teknologi pilihan untuk tracking manusia, produk. Salah satu alasan penggunaan aplikasi interaktif. Selain itu tag juga dapat dibaca dari jarak jauh dan melalui berbagai substasi.

\subsection{Cara kerja Teknologi Radio FrequencyIdentification}

Cara kerja Prinsip kerja RFId sangat singkat adalah komponen utama dari RFId tag yang terdapat chips dan tag antenna (inlay), chip ini berisi informasi dan terhubung dengan tag-antenna. Informasi yang berbeda atau tersimpan di chip akan terkirim atau terbaca melalui gelombang elektromagnetik setelah tag antenna mendapatkan atau 
menerima pancaran gelombang elektromagnetik dari reader antenna (integrator). RFId reader ini yang sekaligus akan meneruskan informasi pada applicarion server.

\subsection{Sistem Informasi Administrasi}

Sistem adalah sebuah kumpulan dari komponen - komponen yang saling berhubungan yang bekerja sama untuk mencapai tujuan dengan menerima masukan-masukan dan menghasilkan output dalam proses transformasi yang terorganisasi (Jogiyanto). Informasi adalah data yang berguna dan dioleh sehingga dapat dijadikan dasar untuk mengambil keputusan (Hutahean, Jeperson).

Sistem informasi adalah kumpulan elemen-elemen atau komponen yang berhubungan yang mengumpulkan, memanipulasi dan menghasilkan data dan informasi serta menyediakan mekanisme balasan untuk mencapai suatu tujuan (Jogiyanto). Administrasi adalah usaha dan kegiatan yang berkaitan dengan penyelengaraan kebijakan untuk mencapai tujuan. Dari teori teori yang telah diuraikan diatas tentang sistem informasi dan administrasi, maka dikatakan bahwa sistem informasi administrasi adalah kumpulan dari komponen-komponen atau elemen-elemen yang saling berhubungan untuk melakukan proses pencatatan, pengaturan, pengalokasian suatu kegiatan untuk mencapai tujuan tertentu dengan mengunakan sarana perlengkapan dan peralatan yang ada (Jogiyanto).

\subsection{Unifield Modeling Language(UML)}

Perancangan berorientasi obyek biasanya menggunakan model yang dikenal dengan Unified Modeling Language (UML) yang merupakan sebuah bahasa pemodelan objek standar sebagai ganti dari pendekatan atau metode berorientasi objek standar. Unified Modeling Language (UML) adalah satu kumpulan konvensi pemodelan yang digunakan untuk menentukan atau menggambarkan sebuah sistem software yang terkait dengan objek. (Jeffrey L, et al).

\subsection{Perancangan Sistem}

Pemodelan sistem berorientasi objek mulai diperkenalkan pada tahun 1990'an yang digunakan sebagai konsep pemograman berorientasi objek, sedangkan yang pertama kali di perkenalkan oleh Ole Johan Dahl dan Kristen Nygaard pada akhir tahun 60án. Alat-alat yang digunakan dalam tahap perancangan sistem adalah sebagai berikut: Entity Relationship Diagram (ERD) adalah model data yang menggunakan beberapa notasi untuk menggambarkan data dalam konteks entitas dan hubungan yang dideskripsikan oleh data tersebut. Entity /Entitas. Kelompok orang, tempat, objek, kejadian atau konsep tentang apa yang kita perlukan untuk men-capture dan menyimpan data (Munawar).

\subsection{Tool Pengembangan Sistem}

Activity Diagram adalah diagram yang menggambarkan workflow (aliran kerja) atau aktivitas dari sebuah sistem atau proses bisnis. Yang perlu diperhatikan adalah bahwa diagram aktivitas menggambarkan aktivitas sistem bukan apa yang dilakukan aktor, jadi aktivitas yang dapat dilakukan oleh sistem. 
Use Case adalah suatu model yang dangat fungsional dalam sebuah sistem yang menggunakan actor dan use case. Sedangkan pengertian dari use case sendiri adalah layanan atau fungsi-fungsi yang tersedia pada sistem untuk penggunannya.

Sequence Diagram Adalah suatu diagram yang memperlihatkan atau menampilkan interaksi-interaksi antar objek di dalam sistem yang disusun pada sebuah urutan atau rangkaian waktu. Interaksi antar objek tersebut termasuk pengguna, display, dan sebagainya berupa pesan/message.

Class Diagram Adalah mendeskripsikan jenis-jenis objek dalam sistem dan berbagai macam hubungan statis yang terdapat di antara mereka.Class diagram juga menunjukan property dan operasi sebuah class dan batasanbatasan yang terdapat dalam hubungan-hubungan objek tersebut.UML menggunakan istilah fitur sebagai istilah umum yang meliputi property dan operasi sebuah class.

\subsection{Analisis SWOT}

Suatu upaya yang dilakukan dalam kegiatan usaha untuk penetapan strategi bisnis. Biasanya, analisis ini menggunakan panduan sistematis atau kerangka dalam menjalankan diskusi agar lebih terarah dan fokus pada hal yang ingin dicapai. Analisis tersebut juga bisa dijadikan sebagai pertimbangan suatu perusahaan untuk mengambil keputusan dalam pengembangan bisnis yang dijalani.

\section{METODOLOGI}

\subsection{Pengumplan Data dan Analisa}

OOAD adalah metode pengembangan sistem yang lebih menekankan pada objek dibandingkan dengan data atau proses. Dalam Tahapan nya OOAD terbagi menjadi dua yaitu OOA (Object Oriented Analysis) Dan OOD (Object Oriented Design). Adapun langkah-langkah dalam OOA pada tahap Pengumpulan data adalah sebagai berikut :

1. Menganalisis masalah : Data-data yang diperlukan untuk pembangunan suatu sistem dikumpulkan sebagai kebutuhan sistem. Setelah semua data-data terkumpul, penulis melakukan analisa untuk merumuskan permasalahan yang terjadi. Kemudian penulis menganalisa dan menggambarkan aliran sistem yang lama dari data yang telah didapat sebelumnya.

2. Menjelaskan proses yang terjadi dalam system : Fungsi dari sistem yang akan dibangun bersumber dari data-data yang diperlukan untuk pembangunan suatu sistem dikumpulkan digambarkan. Pada penelitian ini semua data-data yang diperlukan untuk membuat sistem digambarkan dalam bentuk rancangan analisis. Adapun rancangan analisis yang digunakan pada penelitian ini adalah usecase diagram, class diagram, sequence diagram

3. Identifikasi Objek : Objek adalah benda yang secara fisik dan konseptual yang ada disekitar kita.

4. Menentukan atribut : Atribut disebut juga dengan class yaitu definisi umum dari himpunan objek yang sejenis. Kelas menetapkan spesifikasi perilaku (behaviour) dan atribut-atribut dari objek tersebut. Class adalah abstraksi dari entitas dunia nyata.

5. Mendefinisikan Operasi : Maksudnya yaitu menjelaskan operasi yang memungkinkan bisa untuk di implementasikan dan yang tidak bisa di implementasikan. 


\subsection{Data Responden}

Data responden yang menjadi sampel adalah 7 Bagian Unit Rumah Sakit diantaranya Direktur, Pelayanan Medik, Penunjang Medik, Bidang Keperawatan, instalasi Farmasi, Wadir Umum dan Keuangan.

Adapun tahan dari Object Oriented Design (OOD) yaitu :

1. Desain Subsistem: Berisikan representasi masing-masing subsistem yang memungkinkan perangkat lunak mencapai persyaratan yang didefinisikan oleh pelanggannya dan untuk mengimplementasikan infrastruktur yang mendukung persyaratan pelanggan. Desain subsistem ini menggambarkan tabel-tabel yang digunakan dalam sistem.

2. Desain Objek dan Kelas: Berisi hirarki kelas yang memungkinkan sistem diciptakan dengan menggunakan generalisasi dan spesialisasi yang ditarget secara perlahan. Lapisan ini juga berisi infrastruktur yang mendukung persyaratan pelanggan. Desain objek dan kelas ini meliputi gambaran relasi dari tiap- tiap kelas/objek yang ada pada sistem.

3. Desain Pesan: Berisi detail yang memungkinkan masing-masing objek berkomunikasi dengan kolaboratornya. Lapisan ini membangun interface internal dan eksternal bagi sistem tersebut.

\subsection{Metode Analisa Data}

Dalam penelitian ini penulis menggunakan tools UML (unified modeling language), di mana terdapat 13 macam diagram di dalamnya, namun dari 13 macam diagram tersebut penulis hanya menguakan 6 diagram, yaitu :

1. Activity Diagram: Activity diagram lebih pokus kepada menggambarkan proses bisnis dan urutan aktivitas yang ada di Pecah Belah Center. Dan di pakai pada bussines modeling untuk memperlihatkan urutan aktivitas proses bisnis dan activity di buat berdasarkan sebuah atau beberapa use case pada use case diagram. Dan memiliki manfaat lain yang apabila kita membuat diagram ini terlebih dahulu dalam memodelkan sebuah proses untuk membantu memahami subuah proses secara keseluruhan.

2. Use Case Diagram: Use case diagram menggambarkan kebutuhan sistem yang di butuhkan dan dengan nyata siapa saja yang akan menggunakan sistem dan dengan cara apa pemakai dapat saling berhubungan dengan sistem. Dengan kata lain, use case diagram menggambarkan hubungan antara actor dan use case.

3. Package Diagram: menyediakan cara mengumpulkan elemen-elemen yang saling terkait dalam UML diagram.

4. Class Diagram: Membantu dalam visualisasi struktur kelas dari suatu sistem dan hubungan antar kelas dari penjelasan detail tiap kelas.

5. Deployment Diagram: Deployment diagram merupakan gambaran proses-proses berbeda pada suatu sistem yang berjlan dan bagaimana realissasi di dalamnya. Hal inilah yang mempeermudah user dalam pemakaian sistem yang telah dibuat dan diagram bersipat statis. Misalnya untuk mendeskripsikan sebuah situs web, deployment diagram menunjukan komponen perangkat lunak apa yang berjalan pada setiap note dan bagaimana bagian bagian yang berbeda terhubung.

6. Sequence Diagram: Suatu diagram yang menggambarkan skenario atau rangkaian langkah-langkah yang di lakukan sebagai sebuah respon dari kejadian/event untuk menghasilkan suatu output tertentu. Diagram ini secara khusus bersosialisasi dengan use case diagram, memperlihatkan tahap demi tahap apa yang seharusnya terjadi untuk menghasilkan sesuai di dalam use case.

Meliputi analisis, arsitektur dan metode yang dipakai untuk menyelesaikan permasalahan. Adapun rancangan dari kerangka penelitian dibawah ini : 


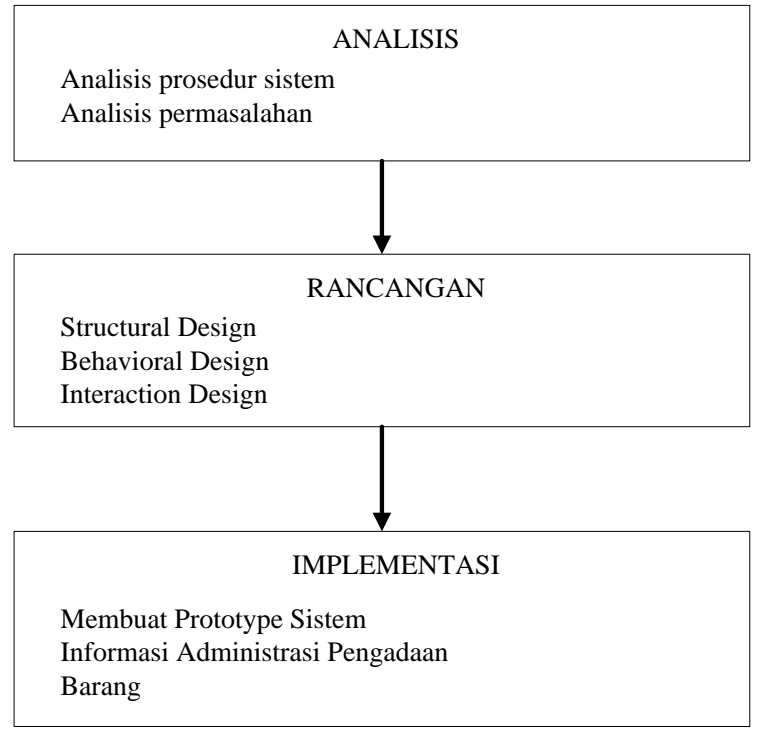

Gambar 1. Kerangka Penelitian

Pada gambar 1 digambarkan tahapan-tahapan penelitian, terdiri dari tahapan analisis, rancangan dan implementasi. Thapan analisis terdiri dari analisis terhadap prosedur sistem dan analisis permasalahan menggunakan analisis SWOT. Pada tahapan rancangan, sistem yang dirancang dengan pemodelan UML terdiri dari structural diagram, behavioral diagram dan interaction diagram. Pada tahapan implementasi dibuat prototipe sistem informasi administrasi pengadaan barang dengan menggunakan teknologi radio frequency identification (RFId).

\section{HASIL DAN PEMBAHASAN}

\subsection{Analisis Prosedur Sistem}

Ka. Adm. Umum menyerahkan data Unit Kerja yang berhak meminta dan menerima ajuan Barang ATK/ART ke gudang ATK/ART. Proses Bisnis Pendataan Rekanan dan Pendataan Barang. Ka. Adm. Umum menyerahkan data nama-nama rekanan dan daftar barang setiap rekanan yang terdaftar sebagai rekanan ke gudang ATK/ART.

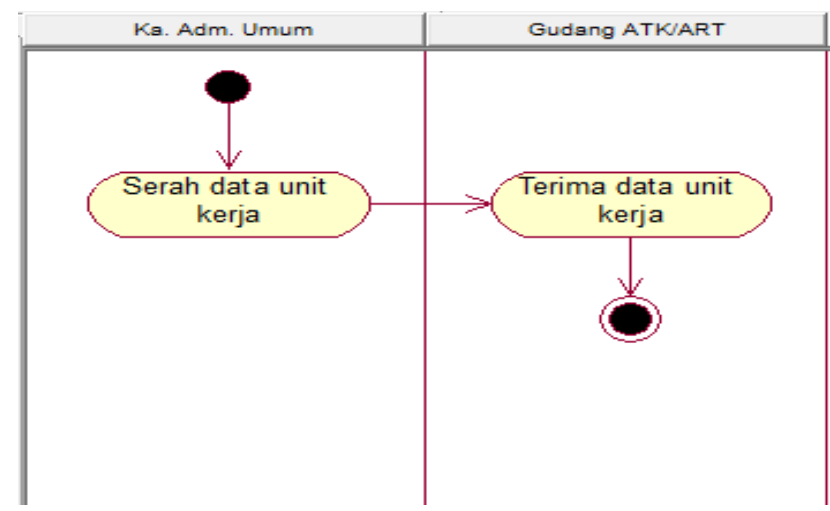

Gambar 2. Data Unit Kerja 


\subsubsection{Proses Bisnis Ajuan Permintaan Barang.}

Unit kerja menyerahkan Formulir Permintaan Barang ATK/ART kepada Atasan langsung (Level 3) untuk mendapatkan persetujuan ajuan permintaan yang di minta.

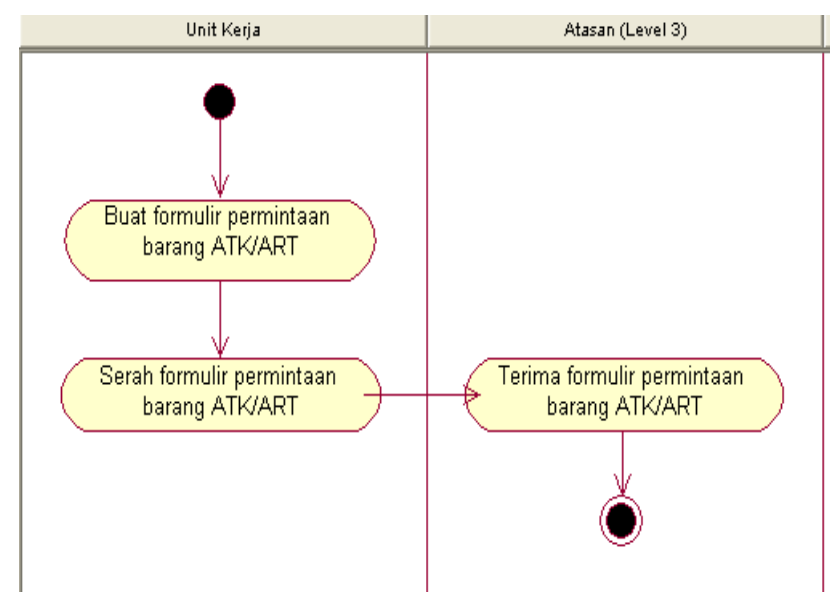

Gambar 3. Ajuan Permintaan Barang ata Unit Kerja

\subsubsection{Proses Bisnis Rekapitulasi Permintaan Barang}

Formulir ajuan permintaan barang ATK/ART yang telah disetujui dari unit kerja diserahkan ke Gudang ATK/ART, kemudian Bagian Gudang ATK/ART menerima formulir ajuan permintaan ATK/ART untuk di rekapitulasi. Proses bisnis pengelompokkan jenis barang dan Rekanan. data rekapitulasi permintaan barang ATK/ART yang terkumpul, kemudian Bagian Gudang ATK/ART memilah barang untuk di kategorikan kepada kelompok Alat Tulis Kantor (ATK) atau kepada kategori Alat Rumah Tangga (ART), kedalam Lampiran Rincian Permintaan. Setelah Kategori Jenis barang di kelompok, Gudang ATK/ART, membagikan barang yang akan dipesan kepada rekanan sesuai dengan Form Permintaan Barang yang telah mendapat item sesuai dengan Surat Perjanjian Kerja (SPK) yang sudah dilampirkan. Bagian Gudang ATK/ART, membuat surat Penempatan Pesanan (PP), untuk di paraf Ka. Adm. Umum, dan di tanda tangani oleh Wakil Direktur Keuangan. Surat Penempaan Pesanan (PP) yang telah di setujui dan di tanda tangani oleh Wakil Direktur Keuangan, selanjutnya di serahkan kepada masing masing Rekanan. Rekanan mengantarkan barang sesuai dengan jumlah dan item yang tertera dalam Surat Penempatan Pesanan. Barang yang telah di terima, kemudian diperiksa, jika telah sesuai dengan jumlah dan item yang ada di Surat Penempatan Pesanan, selanjutnya di buat daftar penerimaa barang dengan di tanda tangani oleh Ka. Adm Umum dan diketahui oleh Ka. Sekretariat. Barang yang sudah lengkap, maka Gudang ATK/ART meng-informasikan kepada seluruh Unit Kerja, untuk mengambil barang yang telah diajukan sebelumnya. 


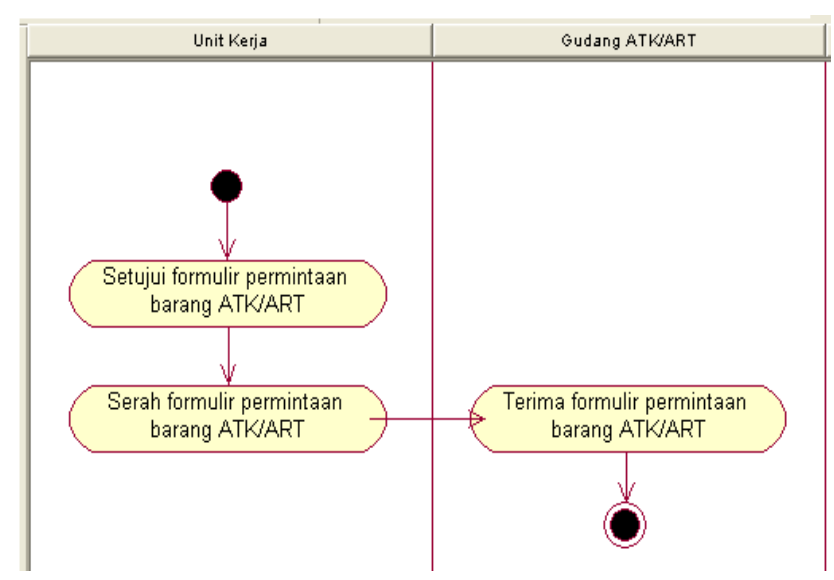

Gambar 4. Rekapitulasi Permintaan Barang

\subsection{Analisis Permasalahan Sistem Informasi}

Analisis terhadap permasalahan sistem informasi administrasi pengadaan barang menggunakan Teknologi Radio Frequency Identification SWOT yang digambarkan pada tabel 1 sebagai berikut :

Tabel 1. Analisis Swot

\begin{tabular}{|c|c|c|}
\hline Faktor Internal & Streng & Weakness \\
\hline Faktor & Memiliki staff & - Pengumpulan \\
\hline \multirow[t]{7}{*}{ Eksternal } & yang & dokumen dan \\
\hline & berpengalaman & pembuatan \\
\hline & dalam proses & tabel masih \\
\hline & penginputan & manual \\
\hline & pengadaan & - Ketidaktelitia \\
\hline & barang. & dalam \\
\hline & & pencatatan \\
\hline Oportuinities & Strategi SO & Strategi WO \\
\hline \multirow{8}{*}{$\begin{array}{l}\text { Perkembangan } \\
\text { IT yang sangat } \\
\text { pesat }\end{array}$} & - Sistem yang & - Membuat \\
\hline & terintegrasi & sistem yang \\
\hline & - Memperkenal & terkomputeris \\
\hline & kan sistem & asi. \\
\hline & pada staff & - Melakukan \\
\hline & & perkenalan \\
\hline & & sistem \\
\hline & & internet. \\
\hline Threath & Strategi ST & Strategi WT \\
\hline - Data hilang & - Staff dituntut & - Membuat \\
\hline - Manipulasi & ketelitian & sistem yang \\
\hline
\end{tabular}


data

$\begin{array}{ll}\text { yang lebih } & \text { terintegrasi. } \\ \text { Sistem yang } & \text { Sistem yang } \\ \text { dijalankan } & \text { terjamin } \\ \text { memiliki } & \text { keamanannya. }\end{array}$

tingkat

keamanan

yang tinggi

Pada tabel analisis SWOT, dilakukan analisa terhadapa kekuatan dan kelemahan, peluang dan ancaman. Kekeuatan dan kelemahan dalam faktor internal, sedangkan kekuatan dn kelemahan termasuk dalam faktor eksternal. Kekuatan nya adaah memiliki staf yang berpengalaman dalam proses penginputan pengadaan barang. Kelemahananya adalah pengumpulan dokumen dan pembuatan tabel masih dilakukan manual dan kurang ketelitian dalam pencatatan. Peluangnya adalah perkembangan IT yang sangat pesat dan ancamannya adalah kehilangan data dan terjadinya manipulasi data. Strategi pada kekuatan dan peluang (SO) adalah merancang sistem yang terintegrasi dan memperkenalkan sistem kepada staf. Strategi pada kelemahan dan peluang (WO) adalah membuat sistem yang terkomputerisasi dan pengenalan sistem internet. Strategi terhadap kekuatan dan ancaman (ST) adalah staf dituntut ketelitian yang lebih dan sistem yang dirancang harus memiliki tingkat keamanan yang tinggu. Strategi terhadap kelemahan dan ancaman (WT) adalah membuat sistem yang terintegrasi dan sistem yang terjamin keamanannya.

\subsection{Rancangan Sistem}

Prototipe Sistem Informasi Pengadaan Barang dengan Menggunakan Teknologi Radio Frequency Identification (RFId) pada Rumah Sakit Bhakti Timah Pangkalpinang yaitu stucture diagram, behavior diagram dan interaction diagram. structure diagram menggunakan class diagram, behavior diagram menggunakan use case diagram dan activity diagram serta interaction diagram menggunakan sequence diagram.

\subsection{Structure Diagram}

Structure diagram yang digunakan adalah class diagram. Dibawah ini adalah class diagram pada sistem Prototipe sistem informasi administrasi pengadaan barang dengan menggunakan RFId. 


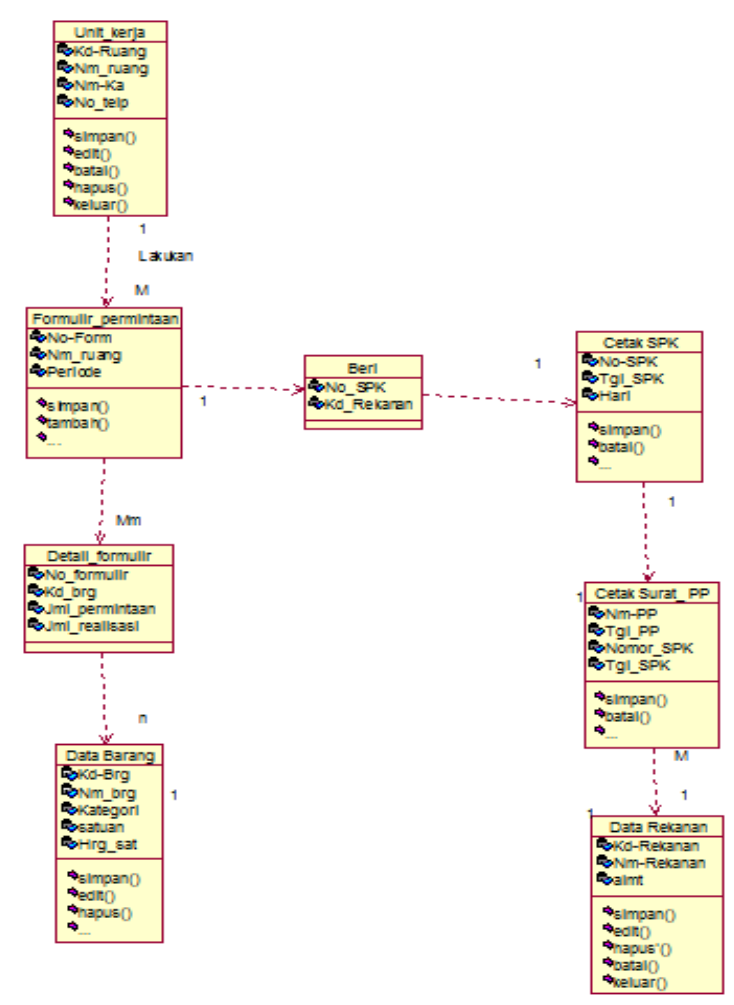

Gambar 5. Class Diagram

Class diagram sangat membantu dalam visualisasi kelas dari suatu sistem. Hal ini disebabkan karena class adalah kelompok objek-objek dan relasi yang sama. Disamping itu class diagram bisa memberikan global sebuah sistem. Class diagram pada gambar diatas terdiri dari beberapa class yaitu class unit_kerja, class formulir_permintaan, class beri, class cetak_SPK, class detail_formulir, class cetak surat_PP, class data_barang, class_rekanan

\subsection{Behavior Diagram}

Behavior diagram yang digunakan adalah use case diagram. Dibawah ini adalah use case diagram Prototipe Sistem Informasi Pengadaan Barang dengan Menggunakan Teknologi Radio Frequency Identification (RFId) pada Rmah sakit Bhakti Timah Pangkalpinang. 


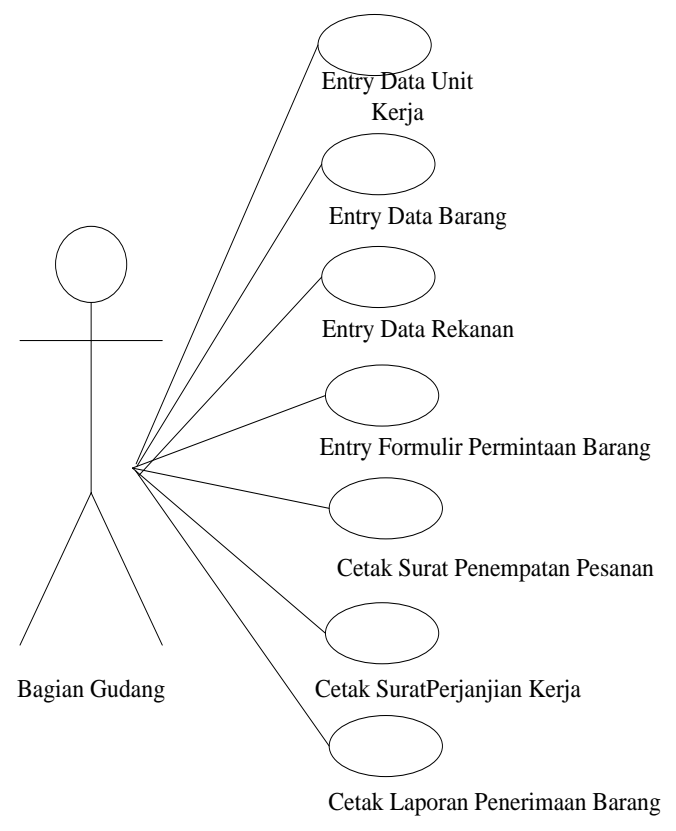

Gambar 6. Use Case Diagram

\subsection{Interaction Design}

Interaction diagram yang digunakan adalah sequence diagram. Dibawah ini adalah sequence diagram pada sistem pengadaan barang formulir permintaan barang

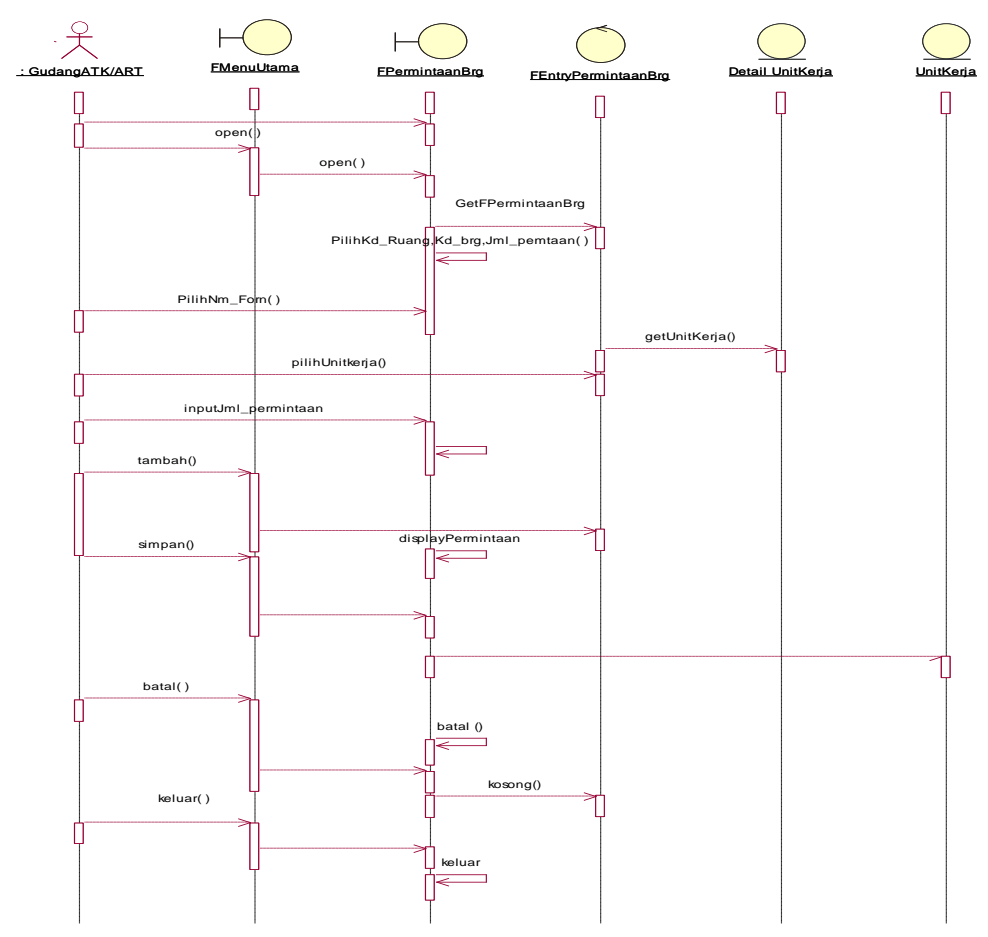

Gambar 7. Sequence Diagram Formulir Permintaan Barang 
Interaction diagram yang digunakan adalah sequence diagram. Dibawah ini adalah sequence diagram pada sistem pengadaan barang, surat penempatan pesanan

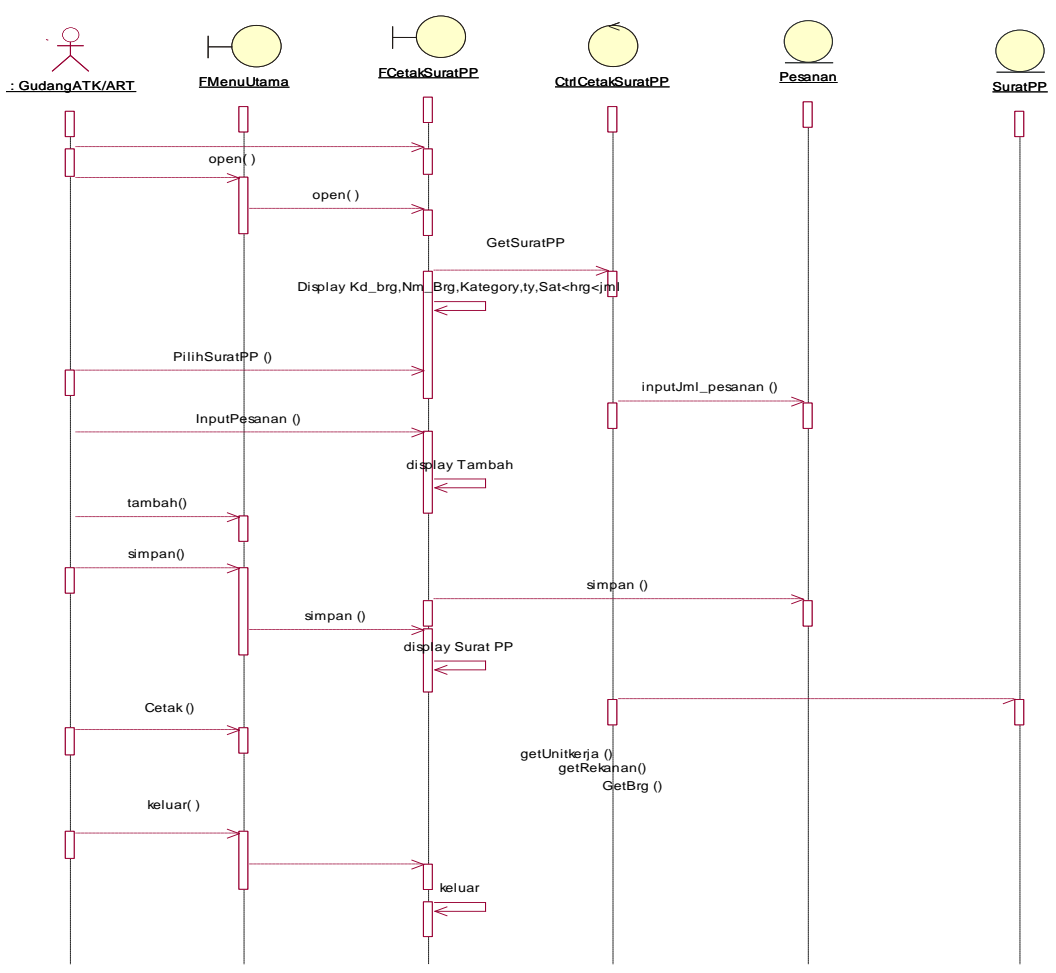

Gambar 8. Sequence Diagram Surat Penempatan Pesanan

Interaction diagram yang digunakan adalah sequence diagram. Dibawah ini adalah sequence diagram pada sistem pengadaan barang laporan penerimaan barang.

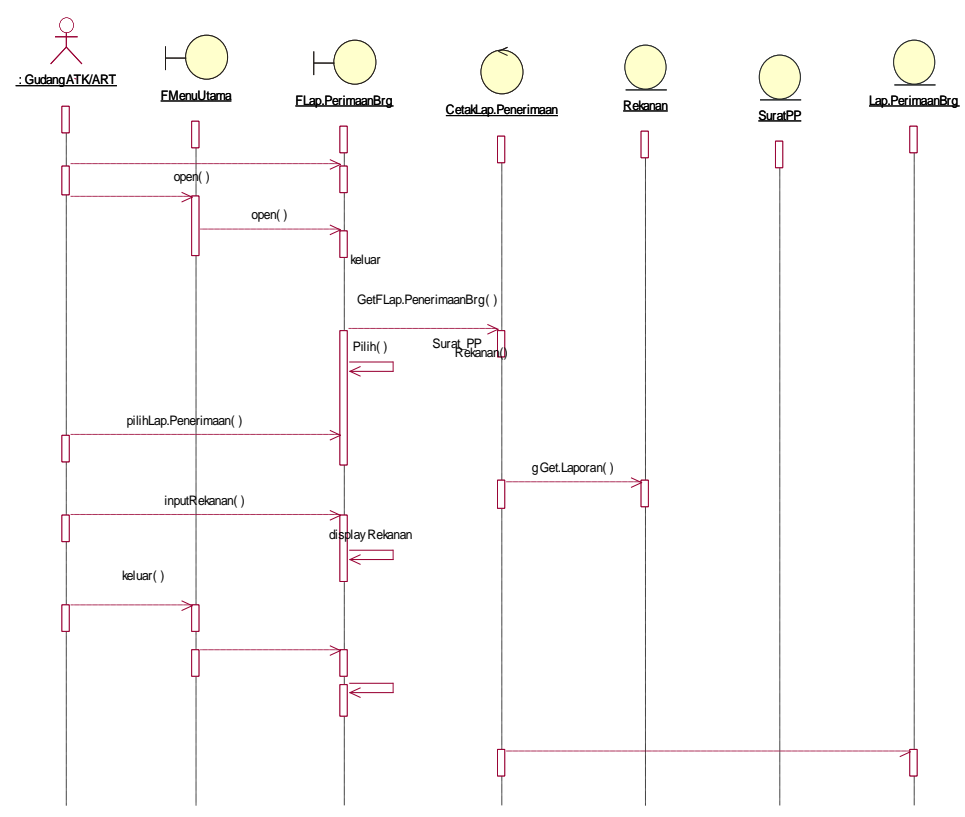

Gambar 9. Laporan Penerimaan Barang 
Perancangan Prototipe Sistem Informasi Administrasi Pengadaan Barang Pada PT. Rumah Sakit Bakti Timah

Pangkalpinang

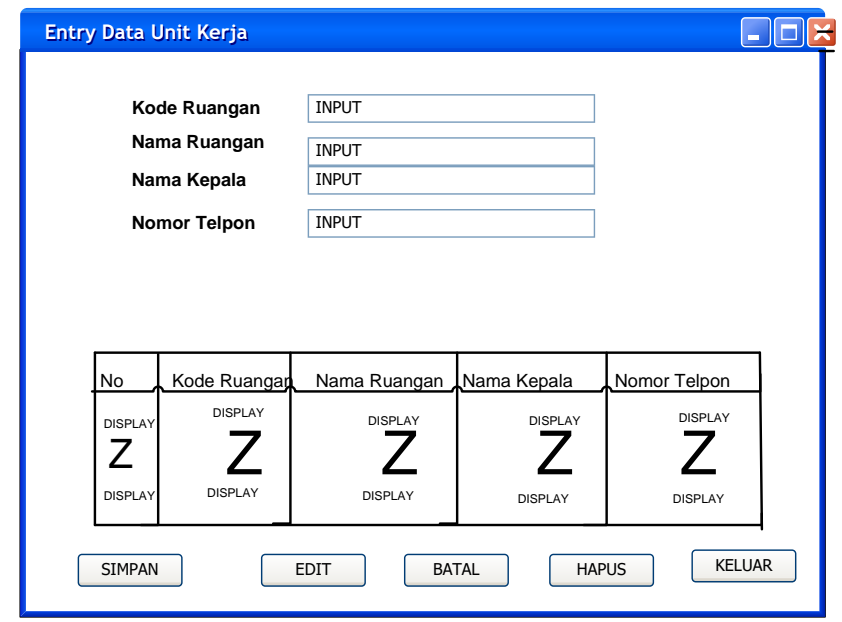

Gambar 10. Rancangan Unit Kerja

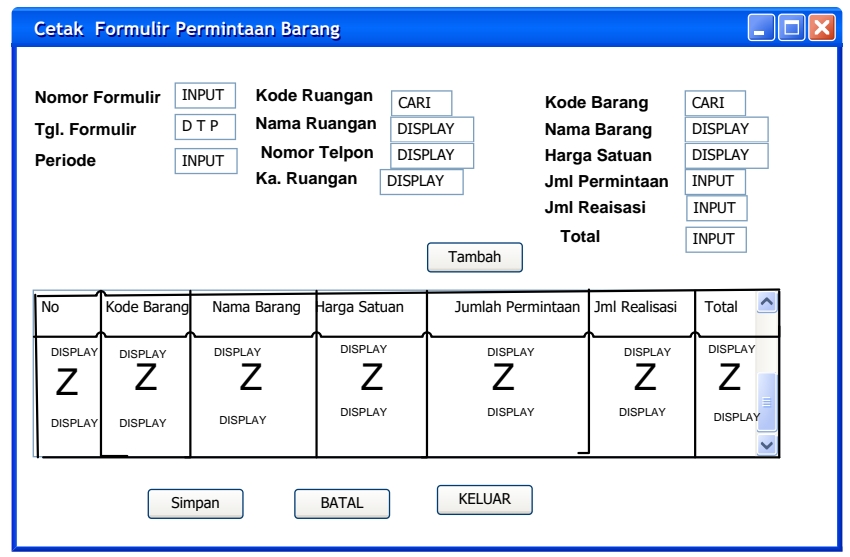

Gambar 11. Rancangan Formulir Permintaan Barang

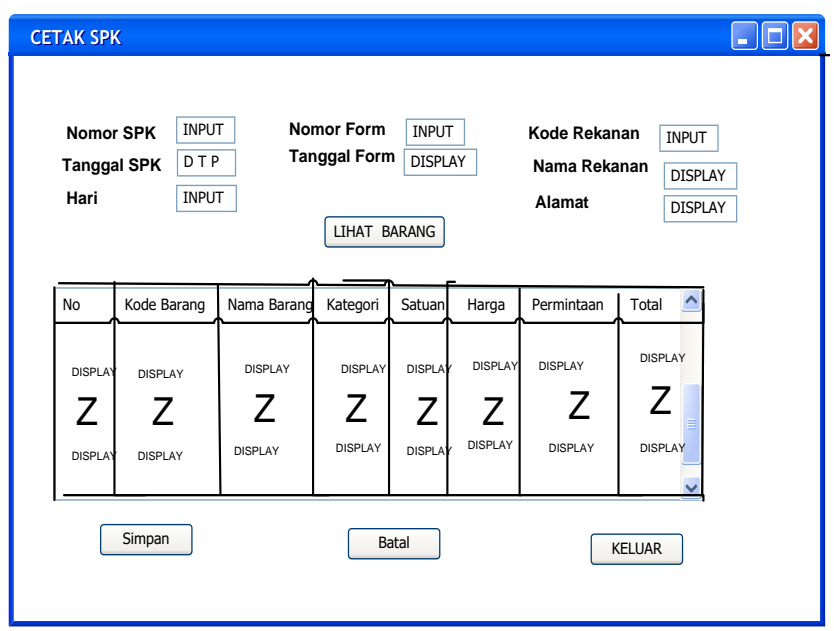

Gambar 12. Rancangan Formulir Surat Perjanjian Kerja 


\section{KESIMPULAN}

Dari hasil penelitian dan pembahasan penelitian diatas terhadap Prototipe sistem informasi Pengadaan barang Dengan Menggunakan Teknologi Radio Frequency Identification (RFId) pada PT. Rumah Sakit Bakti Timah Pangkalpinang, maka dapat ditarik kesimpulan:

1. Prototipe sistem informasi pengadaan barang dengan RFId ini pada PT. Rumah Sakit Bakti Timah Pangkalpinang, maka pihak PT Rumah Sakit Bakti Timah Pangkalpinang dapat menjalankan program baru sesuai yang telah diinginkan dalam hal ini adalah Proses Pengadaan, Pendristibusian dan Pelaporan Barang Umum, yaitu Barang Kategori Alat Tulis Kantor (ATK) ataupun Alat Rumah Tangga (ART).

2. Aplikasi ini bersifat stand alone tanpa terintegrasi, namun dengan menggunakan database yang telah ada. Dan aplikasi ini juga dirancang dengan tampilan yang sederhana namun menarik dan memudahkan bagi petugas yang akan melakukan prosesn Pemesanan dan Pelaporan Pemakaian Barang Umum.sehingga kemudahan dalam pemesanan dan pelaporan data yang di butuhkan dapat menjadi pekerjaan pada Bagian Gudang ATK/ART menjadi suatu halyang dapat di andalkan.

3. Dengan penggabungan teknologi RFId serta sistem informasi maka sistem manajemen pada Bagian Pengadaan Barang serta pendatan barang bisa lebih efisien dan lebih terkontrol oleh pihak rumah sakit.

\section{UCAPAN TERIMA KASIH}

Ucapan terima kasih disampaikan kepada segenap Sivitas akademik Program Studi Sistem Informasi dan Bagian LPPM yang sudah mengurus administrasi kelengkapan pembuatan jurnal ini

\section{DAFTAR PUSTAKA}

Kadir, Abdul., Pengenalan System Informasi, 2015. Penerbit Andi. Jogyakarta.

B. S. Prabhu, Su., Xiaoyong, Ramamurthy., Harish, Chu., Chi-Cheng, \& Gadh., Rajit, WinRFID - A Middleware for the Enablement of Radio Frequency Identification (RFID) Based Applications. 2005. Wireless Internet for the Mobile Enterprise Consortium (WINMEC). UCLA.

Hutahean, Jeperson., 2014. Konsep Dasar Sistem Informasi. Jogyakarta.

Jeffery L., et.al., 2004. Modern Systems Analisys and Design. $4^{\text {th }}$ ed Pearson Prentice Hall. New Jersey.

HM, Jogiyanto., Konsep Dasar Informasi. 2003. Graha Media. Jakarta.

Munawar, Pemodelan UML Berorientasi Objek. 2005. Penerbit Andi. Jogyakarta. 